\title{
Genetic aspects of obesity and metabolic syndrome in people occupationally exposed to arsenic and certain heavy metals
}

\section{Genetyczne aspekty otyłości i zespołu metabolicznego u osób zawodowo narażonych na arsen i niektóre metale ciężkie}

\author{
Tomasz Matys ${ }^{1, B, D, F}$, Anna Szymańska-Chabowska ${ }^{1, B, D, F}{ }^{\oplus}$, Rafał Poręba ${ }^{1, A, E-F \oplus}$, \\ Grzegorz Mazur ${ }^{1, \mathrm{E}-\mathrm{F} \oplus}$, Paweł Gać ${ }^{1, \mathrm{~A}, \mathrm{E}-\mathrm{F} \oplus}$ \\ ${ }^{1}$ Medical University, Wrocław, Poland \\ A - Research concept and design, B - Collection and/or assembly of data, C - Data analysis and interpretation, \\ $D$ - Writing the article, $E$ - Critical revision of the article, $F$ - Final approval of article
}

Matys T, Szymańska-Chabowska A, Rafał Poręba1,A,E-F, Grzegorz Mazur1,E-F, Paweł Gać. Genetic aspects of obesity and metabolic syndrome in people occupationally exposed to arsenic and certain heavy metals. Med Środ. 2019; 22(1-2): 29-32. doi: 10.26444/ms/122202

\begin{abstract}
Introduction. Obesity is a common health issue affecting over 650 million people worlwide. It is an integral element of the metabolic syndrome and leads to the development of arterial hypertension and type 2 diabetes, as well as many other different conditions, including numerous tumours. At the same time, exposure to arsenic, cadmium and lead is increasingly attributed to the development of the metabolic syndrome. Environmentally, this influence concerns the entire population, and is particularly visible in the occupationally exposed population.
\end{abstract}

Objective. The aim of this study is to prevent selected, bestknown elements of the genetic variability and its significance in the development of the metabolic syndrome, taking into account exposure to arsenic, lead and cadmium.

State of the art. CNR1, FTO are related to an increased risk of developing metabolic syndrome, while certain variants of genes responsible for arsenic metabolism (As3MT) and lead (ALAD) are related to their higher toxicity. Knowledge about the relationship between exposure to arsenic, lead and cadmium, and the polymorphism of genes responsible for the development of the metabolic syndrome is scarce. This gap does not appear in more recent research based on the micro RNA expression. Expression of certain miRNA allows detection of both exposure to arsenic and increased risk of cardiovascular episodes in the future, as well as the existence of organ damage at present.

Conclusion. Reinforcement and use of the miRNA knowledge appears to be the right direction, but we should not forget current knowledge about polymorphism of individual nucleotides.

\section{Key words}

metabolic syndrome, obesity, arsenic, cadmium, lead, genetic variability

\section{Streszczenie}

Wprowadzenie. Otyłość jest powszechnym problemem zdrowotnym, dotyczy ponad $650 \mathrm{mln}$ osób na świecie. Jest integralnym elementem zespołu metabolicznego, prowadzi do rozwoju nadciśnienia tętniczego i cukrzycy typu 2, ale też wielu różnych innych schorzeń, w tym licznych nowotworów. Jednocześnie coraz większą wagę przywiązuje się do wpływu narażenia na arsen, ołów i kadm na rozwój zespołu metabolicznego. Wpływ ten środowiskowo dotyczy całej populacji, jednak jest szczególnie widoczny u osób narażonych zawodowo na działanie tych pierwiastków.

Cel pracy. Celem tej pracy jest przedstawienie wybranych najlepiej poznanych elementów zmienności genetycznej i jej znaczenia w rozwoju zespołu metabolicznego z uwzględnieniem narażenia na arsen, ołów i kadm.

Aktualny stan badań. Polimorfizm pojedynczych nukleotydów jest dość dobrze poznany. Poszczególne warianty genów leptyny, CNR1, FTO związane są z większym ryzykiem rozwoju zespołu metabolicznego, a pewnie warianty genów odpowiedzialnych za metabolizm arsenu (As3MT) i ołowiu (ALAD) związane są z większą toksycznością tych pierwiastków. Natomiast wiedza o związku narażenia na arsen, ołów i kadm a polimorfizmami genów odpowiedzialnych za rozwój zespołu metabolicznego jest niewielka. Luki pozbawione są nowsze badania, bazujące na ocenie ekspresji mikroRNA. Ekspresja pewnych mikroRNA pozwala wykryć zarówno narażenie na arsen, jak i zwiększone ryzyko epizodów sercowo-naczyniowych w przyszłości, a także istnienie uszkodzeń narządowych już w chwili obecnej.

Wnioski. Ugruntowanie i wykorzystanie wiedzy o mikroRNA wydaje się słusznym kierunkiem, jednak nie powinniśmy zapominać o posiadanej już wiedzy o polimorfizmie pojedynczych nukletotydów.

\section{Słowa kluczowe}

otyłość, zespół metaboliczny, kadm, arsen, ołów, zmienność genetyczna 


\section{INTRODUCTION}

Obesity is a common medical and economic problem. According to the World Health Organization (WHO), globally there are over 650 million obese and 1.9 billion overweight people [1]. These data are all the more impressive as they keep growing, although this illness is potentially avoidable. The classic definition of obesity is BMI over 30 [2]. A new definition of obesity was formulated by the American endocrinological associations, which defines stage 1 obesity as BMI over 25 and the occurrence of complications of obesity [3]. This definition attempts to draw attention to the fact that obesity is a prelude tor other diseases, particularly from the spectrum of the metabolic complex.

Obesity is an integral part of the classically defined metabolic complex, accompanied by hyperglycaemia, arterial hypertension and dyslipiaemia [4]. Subsequently, there were numerous attempts to expand this definition, yet the changes never gained general acceptance.

Numerous studies were conducted in an attempt to explain the causes of the metabolic complex and obesity. They take into account both the genetic diversity and the effect of the outside environment.

Arsenic, as well as certain heavy metals, such as lead and cadmium, contribute to the onset of metabolic syndrome $[5,6,7]$. Although they are common in nature, there is a particular group of occupationally exposed individuals in which their harmful effects can be particularly evident. One of these groups consists of several thousand employees of the copper smelting plants in the Lower Silesian province of south-west Poland. Apart from the exposed population, heavy metals are also present in tap water. Numerous studies conducted in different sites in Poland have confirmed the presence of metals (especially lead), and in almost every study concentration above acceptable drinking standards were observed. However, over the years tendency of metals concentrations seems positive.

On the other hand, one study showed that the standard monitoring of heavy metals concentrations in Poland is not reliable. Arsenic is a known carcinogen, but its harmful effects, particularly during chronic exposure, are much broader - there were observations of increased cardiovascular risk, peripheral vessel diseases, respiratory system diseases, and neutropaenia [8]. The effect of the arsenic on the development of insulin resistance and diabetes [9] is particularly noticeable. The effects of cadmium exposure mostly include not only thickening of the arterial intima-media, but also renal damage and bone demineralization [9]. The first symptom of chronic lead poisoning is usually anaemia and iron deficiency. These are followed by damage to the kidneys, immune system, or reproductive system [10].

The effect of arsenic, lead and cadmium on the development of the metabolic syndrome is well known. Nevertheless, numerous observations indicate a high individual variability - individuals with the same exposure and similar environmental conditions were observed to have various concentrations of arsenic or lead [11]. This is the effect of a considerable genetic variability of the genes responsible for the broadly-defined metabolism of arsenic, lead and cadmium. Hence, it is difficult to assess the effect of metals on the development of the metabolic syndrome in isolation from individual genetic variability - both responsible for the metabolism of arsenic or lead, and the genes responsible for the development of metabolic syndrome.

The most common well-documented genetic mutations are changes to the genetic polymorphism and micro-RNA variability.

\section{OBJECTVE}

The aim of this study is to present selected, best-known elements of the genetic variability and its significance in the development of the metabolic syndrome, taking into account exposure to arsenic, lead and cadmium.

\section{GENETIC VARIABILITY OF SELECTED GENES RELATED TO THE DEVELOPMENT OF THE METABOLIC SYNDROME - STATE OF THE ART}

Leptin. Leptin is one of the more important and best-known compounds participating in regulating the sense of hunger. It is a hormone produced mostly by adipocytes. It triggers a sense of satiety, stops the sense of hunger, and stimulates the sympathetic nervous system through the interaction with leptin receptors expressed mostly in the hypothalamus. The gene responsible for its production is located on the 7 th chromosome. Both leptin gene polymorphism rs7799039 or leptin receptor gene polymorphism rs 1137101 have clinically relevant single nucleotide polymorphisms. Despite numerous studies, there is no explicit proof of any relationship between the leptine gene polymorphism and obesity [12]. Various genetic models have been studied, including models with dominant and co-dominant expression. On the other hand, new studies have shown a relationship between the leptine gene polymorphism and arterial hypertension, coronary heart disease, or LDL cholesterol concentration [13, 14].

Cadmium exposure has the most evident effect on leptine concentration - cadmium causes the emergence of abnormal, small adipocytes and reduces secretion of leptine, which leads to an increase in insulin resistance, obesity and the development of metabolic syndrome [15]. However, the role of genetic variability in the context of cadmium exposure remains unknown and the authors were unsuccessful in finding studies which consider both genetic variability and cadmium exposure.

CB1. Endogenous cannabinoids, which affect the cannabinoid receptors type 1 (CB1), have similar activity compared to leptine in the context of metabolic syndrome. They are located mostly in different parts of the brain and spine, with little expression in other organs. Their expression prevents development of undue neurological activity. As a result, they are responsible for the feelings of satiety and hunger. Genetic variability of several locations of the gene responsible for the CB1 creation have been described. The best known example is the transformation of adenosine into locus rs 1049353, which causes higher BMI and bigger waist circumference $[16,17]$. There is no obesity without excessive calories in the food. Hence, it is likely that individuals with a specific genetic configuration who eat more food also consume more arsenic and are exposed to its toxic effects. As mentioned before, arsenic directly leads to the development of insulin resistance, and the main route of exposure in the general population 
is food. As commonly known, exogenous cannabinoids stimulate appetite and, as a result, arsenic intake.

Another problem is the accumulation of arsenic and other heavy metals in cannabis plants. These plants accumulate significant amounts of heavy metals, and using its products, either legally or illegally, is connected with heavy metal exposure. In cannabis sativa this accumulation is so great that it is used in the process of phytoremediation - the process of purifying soil from heavy metals by small herbs and plants. An adverse synergy is very likely - a disadvantageous genetic constellation - a genetic predisposition to excessive calorie intake and increased exposure to arsenic, which jointly lead to the development of insulin resistance. However, there are no studies to prove this explicitly.

As3MT. Upon entering the organism, arsenic undergoes methylation and partial reduction, and is then expelled with urine. This process also creates oxygen free radicals and more toxic forms of arsenic, such as monomethylarsonic acid. The main participating enzymes are arsenite methyltransferase (As3MT), purine nucleoside phosphorylase (PNP), or glutathione S-transferase omega-1 (GSTO1) [18]. The genetic variability of the genes responsible for these enzymes leads to various concentration of arsenic in the exposed population, as well as changes in the ratios of individual arsenic forms excreted with urine. It has been demonstrated that certain polymorphic forms of the As3MT gene are related to higher concentrations of dimethylarsinates [19]. In the Mexican population, As3MT gene polymorphisms - in locus rs12767543, rs3740393 and rs11191453 of chromosom 10, were all associated with a high $\mathrm{UDMA} / \mathrm{uMMA}$ ratio. Similar dependences are observed in the Polish population. In turn, higher concentration of the dimethylarsinates increases the insulin resistance by blocking the insulin-dependent transported GLUT4 [20].

Increased insulin resistance is the onset of metabolic syndrome which, after several years, leads to complications and vascular disease, particularly coronary heart disease. As demonstrated by Gong, even a minor, chronic exposure to arsenic, such as drinking ground water, increases the risk of coronary heart disease, the same as the adverse variant of polymorphism As3MT [21]. This risk appears to increase even more when both these factors are combined; however, there is no hard evidence for this.

ALAD. Lead is an inhibitor of several enzymes which participate in the haem synthesis. Its inhibiting effect is the strongest for the delta-aminolevulinic acid dehydratase, displacing zinc from the active enzyme location. Therefore, polymorphism of the gene responsible for production of the delta-aminolevulinic acid is a factor determining the concentration of lead in the serum and its potential toxic effect [22]. Higher lead concentration is also related to the development of metabolic syndrome [23]. It was also found that mixed exposure to heavy metals, including lead, is also related to the development of obesity, arterial hypertension and type II diabetes [7]. The authors, however, failed to find any research investigating a direct connection between the ALAD gene polymorphism and the metabolic syndrome, although this connection appears to be likely.

FTO. The FTO gene (fat mass and obesity-associated gene), commonly known as the obesity gene, is probably the most examined genetic mutation which contributes to the development of obesity. It codes the enzyme alphaketoglutarate dioxygenase responsible for the demethylation of numerous nucleic acid molecules. The latest metaanalyses confirm that the adverse variants of the FTO gene polymorphism are significantly related to obesity [24]. On the other hand, dietary interventions has the same effect, irrespective of one's polymorphic variants, which suggests that environmental interventions and lifestyle prevail over the innate genetic variability [25]. At the same time, there is no known connection between the FTO gene polymorphism and exposure to metals, although, again, one may expect an adverse synergy in the context of metabolic syndrome development.

MICRO-RNA. Apart from polymorphism of individual nucleotides, the literature also broadly discusses the participation of the micro RNA (miRNA) in pathogenesis and development of numerous diseases, e.g. tumours, cardiac and vascular diseases, diabetes and insulin resistance, or immunologic disorders.

MicroRNA is a group of small, non-coding RNA which, in mature form, regulate the gene expression at the posttranscription level. They play an important role in the processes crucial for the proper functioning of cells, and may affect the signal-transferring process and be a part of the mechanism defending the organism against viruses [26].

Numerous miRNA have been identified, both with pro-adipogenic and anti-adipogenic effect. Currently, it is believed that distortion of the miRNA balance leads to the development of obesity and increased insulin resistance, and individual miRNAs are a potential therapeutic target in obesity treatment [27].

The effect of arsenic, lead and cadmium exposure on the miRNA variability is currently widely examined. The number of new reports increases every month, unlike the dependence between polymorphisms - in this case, original and contributing studies are scarce. For this reason, a detailed description of all the miRNAs which number several dozen, exceeds the scope of this study. Explicit examples have been selected which demonstrate the significance of miRNA in the context of environmental and occupational exposure.

In potable water there is a clearly visible effect of arsenic exposure on the expression of miRNA 155 and 126 - the higher the arsenic concentration, the greater the expression of the aforesaid miRNAs. At the same time, there is a reported relationship between the expression of the aforesaid miRNAs and the increase in cardiovascular risk [28]. The discovery of this relationship shows how arsenic directly contributes to an increase in cardiovascular risk. Designation of the expression of these miRNAs allows identification of individuals who are both potentially exposed to arsenic and bear an increased cardiovascular risk.

Moreover, the designation of the miRNA expression allows not only assessment of the cardiovascular risk, or foresee the possibility of incidents in the future, but also to detect current organ damage caused by arsenic. An increased expression of miRNA 155 is of both predictive and diagnostic value for skin damage caused by arsenic exposure. An increased expression of miRNA 21 and 145 has both predictive and diagnostic value for liver damage caused by arsenic, and increased miRNA 181 expression for renal damage [27]. Also, arsenic exposure through drinking contaminated water was found 
to have a potential impact - by an increased expression of individual miRNAs - on the development of large intestine cancer, type 2 diabetes, and damage of the signal pathways in the immune system [29]. Studies on cellular cultures confirmed that it is arsenic, particularly in mixed exposure to arsenic, lead and cadmium, that induces an increased miRNA expression, not any other factors [30].

\section{CONCLUSIONS}

The designation of micro-RNA expression seems to be a promising direction not only in the diagnostics of exposure to arsenic, but also to other metals, such as lead and cadmium. It not only permits the isolation of risk groups, but also an almost direct diagnosing of organ damages caused, for instance, by exposure to arsenic. Further studies of miRNA diversity are still needed which would confirm their significance and isolate specific changes with the highest potential for clinical use. At the same time, one should not forget about the polymorphism of individual nucleotides of the genes responsible both for the development of the metabolic syndrome, and for arsenic metabolism. Although these changes have been known for many years, to-date there has been little success in connecting the relationship between polymorphism of the genes responsible for the development of the metabolic syndrome, and exposure to arsenic and certain heavy metals.

\section{REFERENCES}

1. WHO. Obesity and overweight - key facts. https://www.who.int/newsroom/fact-sheets/detail/obesity-and-overweight (accessed: 2020.01.14).

2. Uzunlulu M, Telci Caklili O, Oguz A. Association between Metabolic Syndrome and Cancer. Ann Nutr Metab. 2016; 68(3): 173-179.

3. Garvey WT, Mechanick JI, Brett EM, Garber AJ, Hurley DL, Jastreboff AM, et al. American Association of Clinical Endocrinologists and American College of Endocrinology comprehensive clinical practice guidelines for medical care of patients with obesity. Endocr Pract. 2016; 22 Suppl 3: 1-203.

4. Tatoń J, Bernas M. Metabolic syndrome - controversies between academic debate and real world medical practice. Endokrynol Otyłość i Zaburzenia Przemiany Mater. 2008; 5(1): 13-26.

5. Bulka CM, Persky VW, Daviglus ML, Durazo-Arvizu RA, Argos M. Multiple metal exposures and metabolic syndrome: A cross-sectional analysis of the National Health and Nutrition Examination Survey 2011-2014. Environ Res. 2019; 168: 397-405.

6. Rhee SY, Hwang YC, Woo JT, Sinn DH, Chin SO, Chon S, et al. Blood lead is significantly associated with metabolic syndrome in Korean adults: An analysis based on the Korea National Health and Nutrition Examination Survey (KNHANES), 2008. Cardiovasc Diabetol. 2013; 12: 9 .

7. Wang X, Mukherjee B, Park SK. Associations of cumulative exposure to heavy metal mixtures with obesity and its comorbidities among U.S. adults in NHANES 2003-2014. Environ Int. 2018; 121(Pt 1): 683-694.

8. Ratnaike RN. Acute and chronic arsenic toxicity. Postgrad Med J. 2003 79(933): 391-396.

9. Rahimzadeh MR, Rahimzadeh MR, Kazemi S, Moghadamnia AA. Cadmium toxicity and treatment: An update. Caspian J Intern Med. 2017; 8(3): 135-145.

10. Gidlow DA. Lead toxicity. Occup Med (Lond). 2015; 65(5): 348-356.
11. Yang Y, Wu J, Sun P. Effects of delta-aminolevulinic acid dehydratase polymorphisms on susceptibility to lead in han subjects from southwestern China. Int J Environ Res Public Health. 2012; 9(7): 2326-2338.

12. Yan J, Wang X, Tao H, Yang W, Luo M, Lin F. Lack of association between leptin G-2548A polymorphisms and obesity risk: Evidence based on a meta-analysis. Obes Res Clin Pract. 2015; 9(4): 389-97.

13. Manriquez V, Aviles J, Salazar L, Saavedra N, Seron P, Lanas F, et al. Polymorphisms in Genes Involved in the Leptin-Melanocortin Pathway are Associated with Obesity-Related Cardiometabolic Alterations in a Southern Chilean Population. Mol Diagn Ther. 2018; 22(1): 101-113.

14. Nowzari Z, Masoumi M, Nazari-Robati M, Akbari H, Shahrokhi N, Asadikaram G. Association of polymorphisms of leptin, leptin receptor and apelin receptor genes with susceptibility to coronary artery disease and hypertension. Life Sci. 2018; 207: 166-171.

15. Kawakami T, Nishiyama K, Kadota Y, Sato M, Inoue M, Suzuki S. Cadmium modulates adipocyte functions in metallothionein-null mice. Toxicol Appl Pharmacol. 2013; 272(3): 625-636.

16. Pawlak M, Milewicz A. Rola układu endokannabinoidowego i polimorfizmów genu CNR1 w powstawaniu otyłości. Endokrynol Otyłość i Zaburzenia Przemiany Mater. 2011: 192-196.

17. de Luis DA, Izaola O, Aller R, Lopez JJ, Torres B, Diaz G, et al. Association of G1359A polymorphism of the cannabinoid receptor gene (CNR1) with macronutrient intakes in obese females. J Hum Nutr Diet. 2016; 29(1): 118-123.

18. Agusa T, Fujihara J, Takeshita $H$, Iwata $H$. Individual variations in inorganic arsenic metabolism associated with AS3MT genetic polymorphisms. Int J Mol Sci. 2011; 12(4): 2351-2382.

19. Hwang YH, Chen YH, Su YN, Hsu CC, Chen YH, Yuan TH. Genetic polymorphism of As3MT and delayed urinary DMA excretion after organic arsenic intake from oyster ingestion. J Environ Monit. 2010; 12(6): 1247-1254.

20. Martin EM, Stýblo M, Fry RC. Genetic and epigenetic mechanisms underlying arsenic-associated diabetes mellitus: a perspective of the current evidence. Epigenomics. 2017; 9(5): 701-710.

21. Gong G, O’Bryant SE. Low-level arsenic exposure, AS3MT gene polymorphism and cardiovascular diseases in rural Texas counties. Environ Res. 2012; 113: 52-57.

22. Onalaja AO, Claudio L. Genetic susceptibility to lead poisoning. Environ Health Perspect. 2000; 108 Suppl 1: 23-8.

23. Park SK, Schwartz J, Weisskopf M, Sparrow D, Vokonas PS, Wright $\mathrm{RO}$, et al. Low-level lead exposure, metabolic syndrome, and heart rate variability: The VA Normative Aging Study. Environ Health Perspect. 2006; 114(11): 1718-1724.

24. Doaei S, Mosavi Jarrahi SA, Sanjari Moghadam A, Akbari ME, Javadi Kooshesh S, Badeli M, et al. The effect of rs9930506 FTO gene polymorphism on obesity risk: a meta-analysis. Biomol Concepts. 2019; 10(1): 237-242.

25. Lappalainen TJ, Tolppanen A-M, Kolehmainen M, Schwab U, Lindström J, Tuomilehto J, et al. The common variant in the FTO gene did not modify the effect of lifestyle changes on body weight: the Finnish Diabetes Prevention Study. Obesity (Silver Spring). 2009; 17(4): 832-836.

26. Zaiou M, El Amri H, Bakillah A. The clinical potential of adipogenesis and obesity-related microRNAs. Nutr Metab Cardiovasc Dis. 2018; 28(2): 91-111.

27.Zeng Q, Zou Z, Wang Q, Sun B, Liu Y, Liang B, et al. Association and risk of five miRNAs with arsenic-induced multiorgan damage. Sci Total Environ. 2019; 680: 1-9.

28. Ruiz-Vera T, Ochoa-Martinez AC, Zarazua S, Carrizales-Yanez L, Perez-Maldonado IN. Circulating miRNA-126, -145 and -155 levels in Mexican women exposed to inorganic arsenic via drinking water. Environ Toxicol Pharmacol. 2019; 67: 79-86.

29. Banerjee N, Das S, Tripathy S, Bandyopadhyay AK, Sarma N, Bandyopadhyay A, et al. MicroRNAs play an important role in contributing to arsenic susceptibility in the chronically exposed individuals of West Bengal, India. Environ Sci Pollut Res Int. 2019; 26(27): 28052-28061.

30. Rojas E, Martinez-Pacheco M, Rodriguez-Sastre MA, Valverde M. As$\mathrm{Cd}-\mathrm{Pb}$ mixture induces cellular transformation via post-transcriptional regulation of Rad51c by miR-222. Cell Physiol Biochem. 2019; 53(6): 910-920. 